\title{
Mechanism of Sodium Modulation of Glomerular Angiotensin Receptors in the Rat
}

\author{
Alessandro Bellucci and Barry M. Wilkes \\ Division of Nephrology and Hypertension, Department of \\ Medicine, North Shore University Hospital, and the Department \\ of Medicine, Cornell University Medical College, \\ Manhasset, New York 11030
}

bstract. Specific binding of ${ }^{125} \mathrm{I}$-angiotensin to high affinity glomerular receptors varies directly with the level of dietary sodium. To investigate the mechanism of sodium regulation of glomerular angiotensin receptors, groups of Sprague-Dawley rats were maintained on one of three levels of sodium intake for at least $5 \mathrm{~d}$ : high sodium (7.39 meq/24 h), moderate sodium $(0.88$ meq $/ 24 \mathrm{~h})$, and low sodium diets $(0.01 \mathrm{meq} / 24 \mathrm{~h})$. An additional group was given low sodium diet with daily injections of furosemide $(1 \mathrm{mg} / \mathrm{kg}$ i.p.). To dissociate the effects of dietary sodium from those of circulating angiotensin II levels on glomerular receptor regulation, a fifth group was placed on high sodium diet and given a continuous infusion of angiotensin via an implanted minipump $(100 \mathrm{ng} / \mathrm{min})$ for $21 \mathrm{~d}$. There was a strong negative correlation $(r=-0.98, P<0.01)$ between plasma angiotensin II and glomerular angiotensin receptor density. Dietary sodium, potassium, or water consumption did not correlate with angiotensin II receptor concentration. The affinity constant did not vary in any of the groups $\left(2.33 \pm 0.30 \times 10^{8} \mathrm{M}^{-1}\right)$. The time course of sodium regulation of glomerular angiotensin II receptors was studied in rats switched from a moderate sodium to either a high sodium diet or a low sodium diet plus furosemide. Receptor density was unchanged at $24 \mathrm{~h}$, varied directly with sodium intake for 1-5 d when induction was maximal, and remained constant for at least $21 \mathrm{~d}$. The time course of receptor regulation

A preliminary report of this work was presented at the 15th Annual Meeting of the American Society of Nephrology, 1982, in Chicago, IL. Address reprint requests to Dr. Wilkes.

Received for publication 12 January 1984 and in revised form 2 July 1984.

J. Clin. Invest.

(c) The American Society for Clinical Investigation, Inc. 0021-9738/84/11/1593/08 $\$ 1.00$

Volume 74, November 1984, 1593-1600 closely paralleled changes in plasma angiotensin II. Additional studies were undertaken to demonstrate that glomerular angiotensin II receptors are down-regulated by circulating hormone. Rats maintained on moderate sodium intake were killed 2 min after the induction of anesthesia with pentobarbital $(50 \mathrm{mg} / \mathrm{kg}$ i.p.) or by rapid decapitation. Despite a 50-fold elevation of plasma angiotensin II in anesthetized rats $(424 \pm 154$ vs. $8.6 \pm 1.0$ $\mathrm{pg} / \mathrm{ml}, P<0.001)$ angiotensin receptor density was unchanged (anesthetized, 1,016 \pm 126 vs. unanesthetized, $1,290 \pm 84 \mathrm{fmol} / \mathrm{mg})$. The infusion of angiotensin II (100 $\mathrm{mg} / \mathrm{min}$ ) for $15 \mathrm{~min}$ or $2 \mathrm{~h}$ into anesthetized rats maintained on moderate sodium intake resulted in a $50 \%$ reduction in specific angiotensin binding that could not be reversed by the dissociation of endogenous angiotensin. These data are compatible with modulation of receptor density by circulating hormone and can not be accounted for by prior receptor occupancy.

\section{Introduction}

The renin-angiotensin system is a major regulator of extracellular fluid volume and sodium homeostasis. In the adrenal gland, angiotensin II binds to specific membrane receptors in the zona glomerulosa to stimulate the production and secretion of aldosterone (1). Aldosterone, in turn, works on the distal nephron to increase sodium reabsorption. In the kidney, specific angiotensin receptors are present in the renal glomerulus, tubule, and medulla (2-4). Although the physiological significance of tubular and medullary angiotensin II receptors is not yet known, a large number of studies have suggested an important physiological role for specific angiotensin binding to the glomerulus (5-7).

Glomerular angiotensin receptors are primarily located on mesangial cells. These cells contain smooth muscle elements that contract in response to physiological amounts of angiotensin II (8-10). When specific angiotensin receptors are occupied by the hormone in the intact isolated glomerulus, there is a decrease in glomerular diameter, which is thought to result in reduced surface area available for filtration. Micro- 
puncture studies have demonstrated that angiotensin infusions result in a marked decline in the glomerular capillary ultrafiltration coefficient $(5,7)$. Thus, morphologic and physiologic studies indicate that angiotensin II is an important regulator of glomerular filtration rate. Although the major emphasis of the control of sodium metabolism by the kidney has been placed on tubular factors, hormonal control of glomerular filtration may alter the amount of filtrate entering the proximal tubule, providing an additional site for the regulation of sodium metabolism. Sodium loading results in an increase in glomerular angiotensin receptor binding and, conversely, sodium depletion is associated with a decrease in binding (11, 12). A previous study demonstrated that down-regulation of glomerular angiotensin II receptors by sodium deprivation could be reversed by angiotensin converting enzyme inhibition, suggesting that plasma angiotensin II was an important regulator of glomerular angiotensin II receptor density (12). We undertook this investigation to further define the mechanisms by which dietary sodium modulates glomerular angiotensin II receptors in the rat.

\section{Methods}

Protocols. These studies were performed on 450 male Sprague-Dawley rats weighing between 175 and $250 \mathrm{~g}$. Three levels of sodium intake were used and designated high, moderate, and low. Rats on high sodium were fed standard Purina rat chow (Ralston Purina Co., Chicago, IL) (sodium ash content $0.42 \%$ ) and given $1 \% \mathrm{NaCl}$ in tap water to drink. The moderate sodium group received standard Purina rat chow and tap water. The low sodium diet was prepared by the method of Hartcroft and Eisenstein (13) and consisted of sucrose (70.5\%), vitamin-free casein $(17.6 \%)$, peanut oil $(4.9 \%)$, sodium-free salt mixture (International Chemical and Nuclear 902920, 4.9\%), and vitamins (International Chemical and Nuclear 90465, 2.2\%). The low sodium rats were given deionized water to drink. The rats were maintained on the appropriate diet until immediately before the experiments.

Three protocols were used. In the first protocol, five groups of rats were maintained on the appropriate diet for a minimum of $5 \mathrm{~d}$. One group was maintained on high sodium diet, another on moderate sodium, and a third on the low sodium regimen. A fourth group of rats was maintained on low sodium diet and given daily injections of furosemide ( $1 \mathrm{mg} / \mathrm{kg}$ i.p.) for $5 \mathrm{~d}$. A fifth group was given high sodium diet to inhibit the renin-angiotensin system, but received a continuous infusion of angiotensin II (100 ng/min) via a subcutaneously implanted mini-osmotic pump (Alza Corp., Palo Alto, CA). Metabolic studies were performed in six rats from each group during the $48 \mathrm{~h}$ before study. Two consecutive 24-h measurements of water intake, urine output, and urinary sodium and potassium were averaged for each of the rats. Urinary sodium and potassium were measured by flame photometry.

In a second protocol, the time course of receptor modulation was studied. Paired groups of four rats were placed on either the high or low sodium plus furosemide regimens and the properties of glomerular angiotensin receptors were studied by Scatchard analysis at 1, 2, 3, 6, or $21 \mathrm{~d}$. Metabolic studies were performed daily as described above.

A third protocol was designed to test the effects of acute angiotensin administration on glomerular receptors. In these experiments rats were anesthetized with sodium pentobarbital $(50 \mathrm{mg} / \mathrm{kg}$ i.p.), and an endotracheal tube (Clay-Adams, Div. of Becton, Dickinson \& Co., Parsippany, NJ; PE240) and femoral artery and femoral vein catheters (PE50) were surgically placed. Mean arterial blood pressure was recorded continuously on a Grass Model 7 polygraph with Statham P23DC transducers. Angiotensin II ( $100 \mathrm{ng} / \mathrm{min})$ was infused intravenously with a Harvard pump (Harvard Apparatus Co., S. Natick, MA) and resulted in a maximum increase in mean arterial pressure of $59.4 \pm 2.0 \mathrm{mmHg}$. At the appropriate times, rats were killed and glomerular angiotensin II receptors were measured.

Preparation of isolated glomeruli. Glomeruli were isolated by modification of a method of Fong and Drummond (14). Rats were killed by rapid decapitation unless otherwise noted. Bilateral nephrectomies were performed without renal artery perfusion, and the kidneys were immediately chilled to $4^{\circ} \mathrm{C}$ in phosphate-buffered saline (pH 7.5). The outer cortex was dissected and minced to pastelike consistency and resuspended in buffer. The suspension was buttered through a 106- $\mu \mathrm{m}$ sieve, passed through a 22-gauge needle, and centrifuged at $120 \mathrm{~g}$ for $90 \mathrm{~s}$. The supernatant was discarded and the pellet was resuspended. This step was repeated five times. The final pellet was washed on a $76-\mu \mathrm{m}$ sieve and the glomeruli were recovered from the top of the sieve and resuspended in Hank's medium (pH 7.5). The resulting glomerular suspension was $>\mathbf{9 5 \%}$ pure, as determined by light microscopy, and was adjusted to a standard amount of protein by using the method of Lowry et al. (15).

Receptor binding experiments. The binding of the angiotensin II to isolated glomeruli was assessed as previously described (16). Glomeruli were incubated at $22^{\circ} \mathrm{C}$ for 20 min under continuous gentle shaking. The incubation medium consisted of $200 \mu$ l of Hank's solution (Gibco Laboratories, Grand Island, NY; 310-4060) containing $1.2 \mathrm{mM}$ calcium, $0.9 \mathrm{mM}$ magnesium, $5 \mathrm{mM}$ dithiothreitol, $100 \mu \mathrm{M}$ bacitracin, $0.1 \mathrm{mM}$ phenylmethylsulfonyl floride, $2 \%$ bovine serum albumin, $60 \mu \mathrm{g}$ of glomerular protein, and varying amounts of ${ }^{125} \mathrm{I}$-angiotensin II $(1,800 \mu \mathrm{Cl} / \mu \mathrm{g}$ sp. act., New England Nuclear, Boston, MA) and unlabeled angiotensin II. Scatchard analysis was performed by using a constant specific activity of ligand at each concentration of angiotensin II. Bound and free radioactivity were separated by filtration through a millipore filter (HAWP 02500, Millipore Corp., Bedford, MA). ${ }^{125}$ I was counted in a Packard Auto Gamma spectrometer (Packard Instrument Co., Downers Grove, IL) with $80 \%$ efficiency. Specific binding was calculated by subtracting the binding in the presence of $10^{-6} \mathrm{M}$ unlabeled angiotensin II from the total binding. The nonspecific binding was due to binding of ${ }^{125} \mathrm{I}$-angiotensin II to the filter and was $<1 \%$ of total counts added. The integrity of ${ }^{125}$ I-angiotensin II during incubation was assessed by thin-layer chromatography as previously described (16).

Rebinding experiments. Isolated glomeruli were incubated for 20 min with angiotensin II. After equilibrium was reached between angiotensin II and its glomerular receptors, $3 \mathrm{M}$ magnesium chloride was added to the incubation mixture to dissociate bound angiotensin II from the receptor (17). Glomeruli were subsequently washed and resuspended in Hank's medium, reincubated with the appropriate concentration of angiotensin II, and subjected to Scatchard analysis as described above.

Angiotensin radioimmunoassay. Angiotensin I and angiotensin II were measured in separate radioimmunoassay systems by modification of methods previously described (16). In brief, blood samples obtained by rapid decapitation were immediately placed into chilled test tubes containing $0.01 \mathrm{M}$ EDTA and $30 \mu \mathrm{l}$ of $5 \%$ diisopropylfluorophosphate. Samples were extracted with $2 \mathrm{vol}$ of acetone and the supernatant was 
evaporated to dryness at $4^{\circ} \mathrm{C}$. Dry extracts were reconstituted in 0.5 $\mathrm{ml}$ of assay diluent, the appropriate antibody and $\sim 1 \mathrm{pg}$ of ${ }^{125} \mathrm{I}$-angiotensin were added, and the reaction was carried out for $48 \mathrm{~h}$ at $4^{\circ} \mathrm{C}$. Bound and free hormone were separated by using dextrancoated charcoal and Tris buffer. Free hormone was counted in a Packard Auto Gamma spectrometer (Packard Instrument Co.) until $10,000 \mathrm{cpm}$ were accumulated. The angiotensin I antiserum used did not cross-react with angiotensin II; angiotensin II antiserum crossreacted to a small extent with angiotensin I $(0.0128 \mathrm{wt} / \mathrm{wt})$. Angiotensin II values were adjusted for the contribution of angiotensin I.

Data analysis. Data are presented as the mean \pm SE, unless otherwise indicated. Equilibrium binding studies were analyzed by Scatchard transformation, which consistently gave a straight line by least squares $(r=0.94 \pm 0.01, n=29)$. The affinity constant $\left(K_{\mathrm{A}}\right)^{1}$ was calculated as the negative of the slope of this line, and the concentration of receptors was calculated from the $x$-intercept. The $t$ test was used to compare differences in receptor number among the groups. Where appropriate, linear regression analysis and analysis of covariance were applied. The null hypothesis was rejected when the $P$ value was $<0.05$.

\section{Results}

Under the conditions of our study, hormone-receptor equilibrium was achieved by $15 \mathrm{~min}$ (Fig. 1). The addition of $10^{-6}$ $M$ unlabeled angiotensin II at equilibrium resulted in rapid dissociation of the ligand from the receptor. Under the conditions of our receptor assay, recovery of ${ }^{125} \mathrm{I}$-angiotensin II by thin-layer chromatography was unaffected by sodium intake; $92 \pm 1 \%(n=3)$ and $88 \pm 2 \%(n=3)$ of the ligand co-migrated with true ${ }^{125}$ I-angiotensin II in the high and low sodium groups, respectively.

Scatchard analysis of angiotensin II binding to glomerular protein showed one class of high affinity receptors as demonstrated by linear Scatchard plots and a Hill slope of 1.01 (Fig. 2). Angiotensin receptor density on the renal glomerulus varied directly with sodium intake (Fig. 3). Changes in angiotensin binding associated with changes in dietary sodium could not be explained by changes in hormone-receptor affinity. The affinity of angiotensin for its receptor $\left(K_{\mathrm{A}}\right)$ was virtually identical in animals consuming high sodium $\left(2.21 \pm 0.29 \times 10^{8}\right.$ $\left.\mathrm{M}^{-1}\right)$, moderate sodium $\left(2.37 \pm 0.20 \times 10^{8} \mathrm{M}^{-1}\right)$, or low sodium diets $\left(2.23 \pm 0.23 \times 10^{8} \mathrm{M}^{-1}\right)$.

The results of metabolic studies are summarized in Table I. Water intake closely paralleled sodium ingestion in rats on high sodium, moderate sodium, low sodium, and low sodium plus furosemide regimens. Rats receiving both high dietary sodium and angiotensin infusions had twice the water intake of rats on high dietary sodium alone, an observation compatible with the known dipsogenic action of the hormone. Sodium excretion was $7.39 \pm 0.78 \mathrm{meq} / 24 \mathrm{~h}$ in the high sodium group, $0.88 \pm 0.14 \mathrm{meq} / 24 \mathrm{~h}$ in the moderate sodium group, and $0.010 \pm 0.003 \mathrm{meq} / 24 \mathrm{~h}$ in the low sodium group. Rats receiving low sodium diet plus furosemide had a greater than 20 -fold increase in urinary sodium when compared with the low

1. Abbreviation used in this paper: $K_{\mathrm{A}}$, affinity constant.

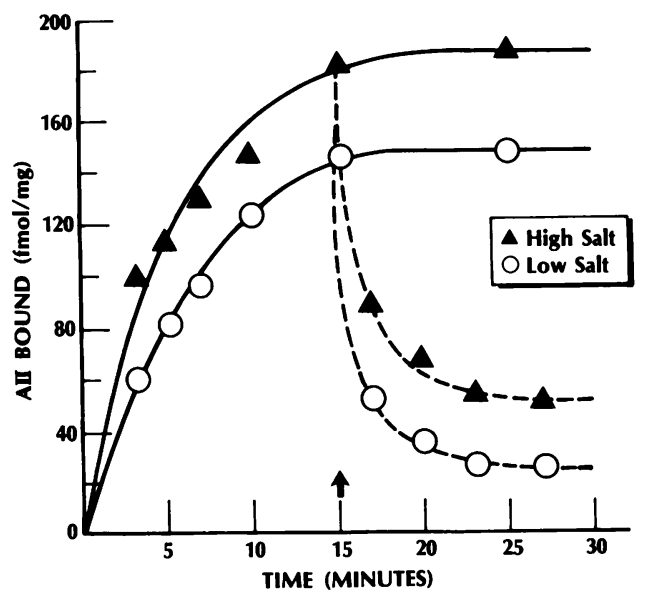

Figure 1. Kinetic binding analysis of angiotensin II (AII) to isolated renal glomeruli. Glomeruli were obtained from rats maintained for 1 wk on high sodium or low sodium diets. In each group after the addition of ${ }^{125} \mathrm{I}$-angiotensin II $\left(30 \times 10^{-10} \mathrm{M}\right)$ receptor equilibrium was reached by $15 \mathrm{~min}$. The addition of $10^{-6} \mathrm{M}$ unlabeled angiotensin II at equilibrium (arrow) resulted in rapid dissociation of the ligand from the receptor.

sodium group $(P<0.001)$, demonstrating an ongoing negative sodium balance. Rats on the high sodium diet plus angiotensin infusion had more than twice the sodium intake of those animals on high sodium diet alone. Potassium excretion was relatively constant in all groups.

Plasma angiotensin levels are summarized in Fig. 4, lower panel. There was a significant rise in plasma angiotensin in rats on a low sodium diet (normal, $13.0 \pm 2.5$ vs. low sodium, $36.0 \pm 4.2 \mathrm{pg} / \mathrm{ml}$ ) with a further increase in plasma angiotensin
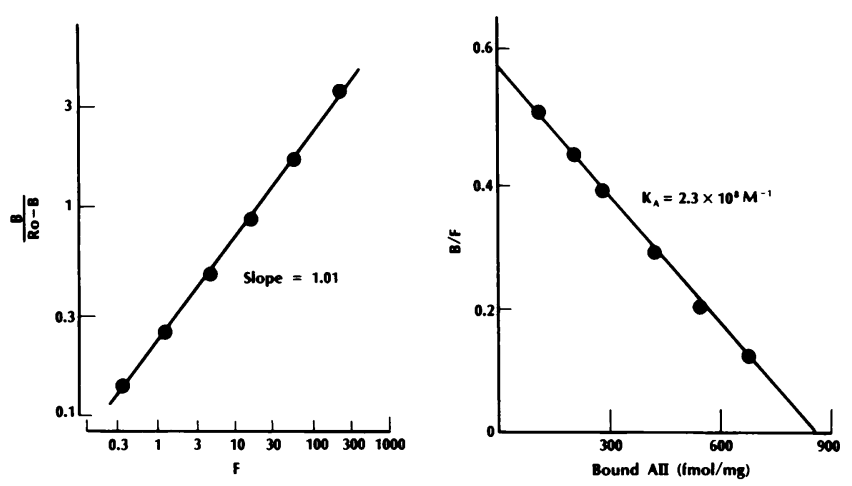

Figure 2. Representative Hill and Scatchard plots of angiotensin II (AII) binding to glomeruli isolated from rats maintained on a moderate sodium diet. The Scatchard plot $(r i g h t)$ is linear $(r=0.997)$ in the concentration range studied $\left(6.3 \times 10^{-10} \mathrm{M}-1.5 \times 10^{-8} \mathrm{M}\right)$. Hill transformation of the same experiment (left) gave a slope of 1.01, compatible with one class of receptors. Each point is the mean of triplicate determinations. B, bound angiotensin II; F, free angiotensin II; Ro, receptor density. 

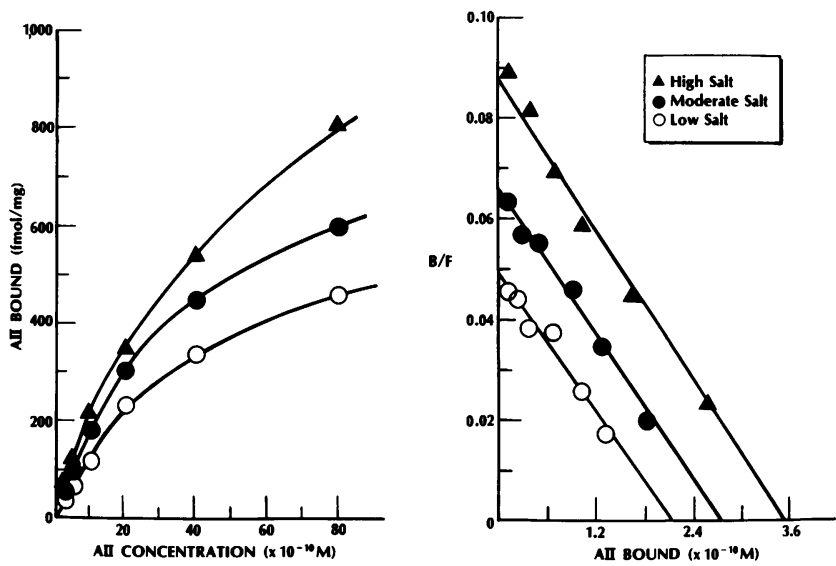

Figure 3. Equilibrium binding analysis (left) and Scatchard plots (right) of angiotensin II (AII) binding to glomeruli isolated from rats maintained on a high, moderate, and low salt diet. Changes in dietary sodium did not affect hormone-receptor affinity as demonstrated by the parallel lines. Receptor density varied directly with sodium intake (see text). Each point is the mean of triplicate determinations.

II in the low sodium-plus-furosemide group (104.7 \pm 11.7 $\mathrm{pg} / \mathrm{ml}$ ). Plasma angiotensin was suppressed in those animals on high sodium intake $(8.0 \pm 1.1 \mathrm{pg} / \mathrm{ml})$. When animals consuming high sodium were given concomitant subcutaneous infusion of angiotensin, plasma hormone levels rose to $174.9 \pm 37.0 \mathrm{pg} / \mathrm{ml}$.

Glomerular angiotensin receptor density varied directly with sodium intake and inversely with plasma hormone levels in those animals consuming high, moderate, and low sodium, and low sodium with furosemide regimens (Fig. 4). When plasma angiotensin and sodium intake were dissociated in the group receiving high sodium intake and continuous infusion of angiotensin II, the relationship between circulating hormone

Table I. Metabolic Studies in Rats

Maintained on the Various Protocols

\begin{tabular}{lccc}
\hline & $\begin{array}{l}\text { Water } \\
\text { intake }\end{array}$ & $\mathrm{U}_{\mathrm{Ne}^{\circ}} \mathrm{V}$ & $\mathrm{U}_{\mathrm{k}} \times \mathrm{V}$ \\
\hline & $m l / 24 \mathrm{~h}$ & $m e q / 24 \mathrm{~h}$ & $m e q / 24 \mathrm{~h}$ \\
& $57 \pm 5$ & $7.39 \pm 0.78$ & $3.0 \pm 0.3$ \\
$\mathrm{High}^{+} \mathrm{Na}^{+}$diet & $37 \pm 3$ & $0.88 \pm 0.14$ & $1.4 \pm 0.2$ \\
$\begin{array}{l}\text { Moderate } \mathrm{Na}^{+} \text {diet } \\
\text { Low } \mathrm{Na}^{+} \text {diet }\end{array}$ & $27 \pm 2$ & $0.010 \pm 0.003$ & $2.6 \pm 0.6$ \\
$\begin{array}{l}\text { Low } \mathrm{Na}^{+} \text {diet plus } \\
\text { furosemide }\end{array}$ & $28 \pm 3$ & $0.23 \pm 0.04$ & $1.3 \pm 0.2$ \\
$\begin{array}{l}\text { High } \mathrm{Na}^{+} \text {diet plus } \\
\quad \mathrm{AII} \text { infusion }\end{array}$ & $113 \pm 12$ & $16.0 \pm 1.32$ & $4.4 \pm 0.4$ \\
\hline
\end{tabular}

Data are the mean $\pm \mathrm{SE}$. Six rats were studied in each group. $\mathrm{U}_{\mathrm{Na}^{+}} \mathrm{V}$ and $\mathrm{U}_{\mathrm{K}} \mathrm{V}$, total urinary sodium and potassium excretion, respectively.
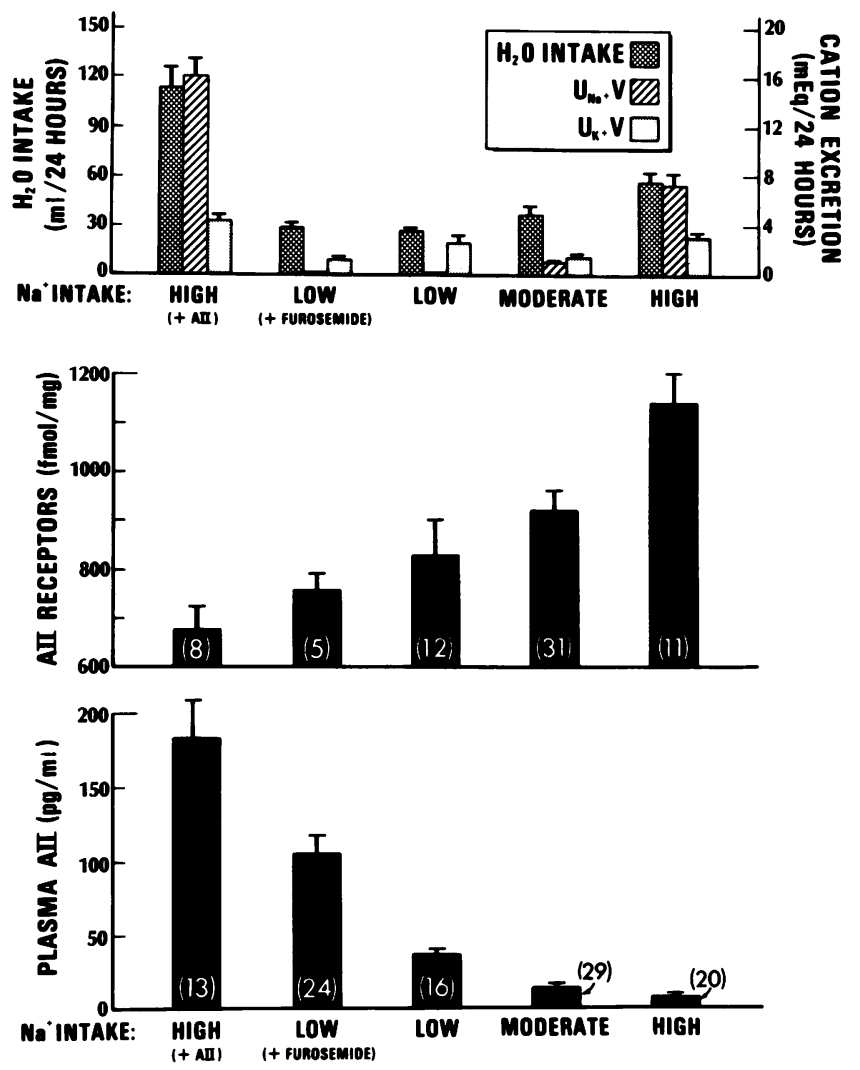

Figure 4. Relationship between fluid and electrolyte balance (upper), plasma angiotensin II (AII) concentration (lower) and glomerular angiotensin receptor density (middle). Receptor number varied directly with the level of sodium intake and inversely with plasma angiotensin II in all the groups studied except in animals maintained on a high sodium diet and constant angiotensin II infusion. In the latter group, receptor regulation followed plasma angiotensin II levels, and not sodium intake. No relation could be established between water consumption and potassium intake (upper) and receptor density. The numbers in the bars represent the number of experiments. Metabolic studies were performed on six rats in each group.

and receptor density remained, but the relationship between sodium intake and receptor density did not. There was a strong relationship between plasma angiotensin and its receptors, as demonstrated by a significant correlation between the reciprocal of circulating hormone level and glomerular angiotensin receptor density $(r=0.98, F=34.8, P=0.008$, Fig. 5). No significant correlation was found between sodium excretion $(r=0.50, F=1.02, P=0.39)$, potassium excretion $(r=0.09, F=0.02, P=0.88)$, or water intake $(r=0.26$, $F=0.22, P=0.67)$ and glomerular receptor density.

Additional studies were performed to assess the time course of dietary sodium-induced glomerular receptor regulation. Rats were studied at 24,48 , and $72 \mathrm{~h}, 6 \mathrm{~d}$, and $3 \mathrm{wk}$ after the initiation of high or low sodium-plus-furosemide regimen. Significant changes in sodium balance were present by $24 \mathrm{~h}$, 


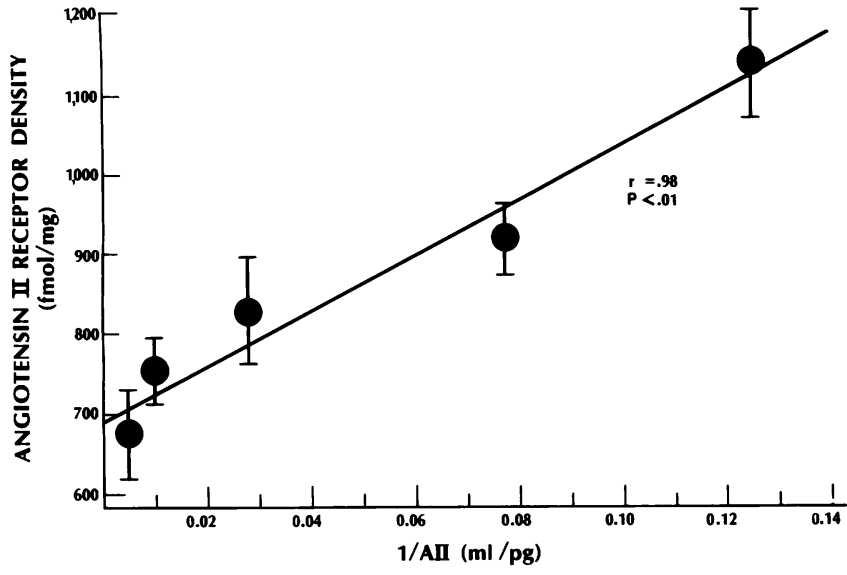

Figure 5. The relationship between glomerular receptor density and plasma angiotensin II (AII). There was a strong correlation between the reciprocal of plasma angiotensin II and glomerular angiotensin II receptor density. $r=0.98 ; P<0.01$.

but sodium-induced changes in receptor density could not be detected until $48 \mathrm{~h}$ (Fig. 6, Table II). Glomerular angiotensin receptor regulation occurred between $48 \mathrm{~h}$ and $6 \mathrm{~d}$ and remained constant over the next 2-3 wk.

To test the hypothesis that circulating hormone is a major regulator of glomerular angiotensin receptor density, the effects of acute elevation in circulating angiotensin II were studied. General anesthesia is a well-known stimulus for the reninangiotensin system (18). 2 min after inducation of anesthesia with sodium pentobarbital, plasma angiotensin II levels had risen to $424 \pm 154 \mathrm{pg} / \mathrm{ml}$ (control, $13.0 \pm 2.0 \mathrm{pg} / \mathrm{ml}, P<0.001$ )

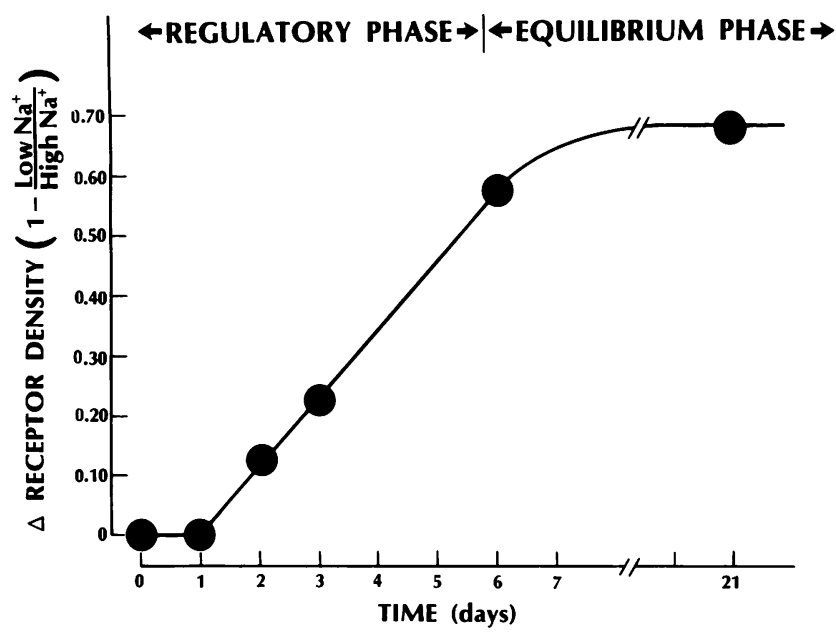

Figure 6. Time course of glomerular angiotensin receptor regulation by dietary sodium. No significant changes in receptor density were observed in the initial $24 \mathrm{~h}$ after initiation of low or high sodium diets. Receptor regulation occurred between 1 and $6 \mathrm{~d}$ and remained stable for the next $2 \mathrm{wk}$. Each point represents the mean of at least two individual experiments. SEM lie within the points. but receptor density did not change $(1,016 \pm 126$ vs. control, $929 \pm 84 \mathrm{fmol} / \mathrm{mg}$ ). When angiotensin II infusions were performed for either $15 \mathrm{~min}$ or $2 \mathrm{~h}$, marked down-regulation of glomerular receptor density occurred. After $15 \mathrm{~min}$ of angiotensin II infusion, receptor density fell to $<50 \%$ of control values (control, $699 \pm 59 \mathrm{pg} / \mathrm{ml}$, angiotensin II infusion $349 \pm 41$ $\mathrm{pg} / \mathrm{ml} P<0.001$ ). Longer angiotensin II infusion time up to $2 \mathrm{~h}$, did not result in further down-regulation.

Apparent down-regulation of hormone receptor density may be due to receptor occupancy. To test this hypothesis, ${ }^{125}$ I-angiotensin II was incubated with glomeruli isolated from normal or 15-min angiotensin II-infused rats under the standard incubation conditions. The addition of $3 \mathrm{M} \mathrm{MgCl}_{2}$ to glomeruli completely dissociated the hormone off its receptor (Fig. $7 \mathrm{~A}$ ). Rebinding of angiotensin to glomeruli pretreated with $\mathrm{MgCl}_{2}$ demonstrated significantly lower binding in glomeruli isolated from rats that had undergone continuous angiotensin II infusion (Fig. $7 \mathrm{~B}$ ). Therefore, decreased binding of angiotensin II to glomeruli isolated from rats infused with angiotensin II can not be accounted for by receptor occupancy.

\section{Discussion}

These studies demonstrated that a major mechanism by which dietary sodium regulates glomerular angiotensin receptor density is via changes in plasma angiotensin. There was a strong inverse relationship between angiotensin receptor density and circulating hormone $(r=0.98, P<0.01)$. When experimental conditions were manipulated to produce both high dietary sodium and high plasma angiotensin, receptor regulation was inversely related to the circulating hormone and not to sodium intake.

Changes in dietary sodium for $24 \mathrm{~h}$ did not result in detectable changes in plasma angiotensin or in glomerular angiotensin receptor density, despite significant changes in sodium balance. Between days 1 and 6 receptor density fully regulated (paralleling the changes in plasma angiotensin), and remained stable for up to $3 \mathrm{wk}$ when the level of sodium intake was kept constant. Induction of high circulating angiotensin levels by pentobarbital anesthesia was not associated with receptor regulation at $2 \mathrm{~min}$. After a 15-min infusion of angiotensin II, however, receptors had down-regulated by $50.1 \%$. There was no further down-regulation after a 2-h angiotensin infusion. Receptor density could not be restored by pretreating glomeruli with magnesium chloride, a maneuver known to dissociate angiotensin II off its receptor (17). These data support rapid down-regulation of angiotensin receptor density in renal glomeruli.

Changes in angiotensin receptor density by dietary sodium have been described in several tissues, including the renal glomerulus $(11,12)$ and vascular smooth muscle (17). Previous studies (11) described down-regulation of glomerular angiotensin receptor density by sodium restriction and up-regulation by sodium surfeit, but the mechanism(s) of sodium regulation 
Table II. Sodium and Angiotensin II during Receptor Regulation

\begin{tabular}{|c|c|c|c|c|}
\hline Diet regimen & Control (moderate sodium group) & $1 \mathrm{D}$ after diet change & $3 \mathrm{D}$ after diet change & $6 \mathrm{D}$ after diet change \\
\hline \multicolumn{5}{|l|}{ High sodium } \\
\hline $\begin{array}{l}24 \mathrm{~h} \mathrm{U}_{\mathrm{Na}^{+}} \mathrm{V} \\
\quad(m e q)\end{array}$ & $\begin{array}{l}0.88 \pm 0.14 \\
(6)\end{array}$ & $\begin{array}{l}2.77 \pm 0.64 \ddagger \\
(6)\end{array}$ & $\begin{array}{l}6.91 \pm 1.22 \S \\
(8)\end{array}$ & $\begin{array}{l}7.15 \pm 0.92 \S \\
\text { (7) }\end{array}$ \\
\hline $\begin{array}{l}\text { Plasma angiotensin II } \\
\quad(p g / m l)\end{array}$ & $\begin{array}{l}12.6 \pm 3.0 \\
(29)\end{array}$ & $\begin{array}{l}16.0 \pm 5.2 \\
(7)\end{array}$ & $\begin{array}{l}9.23 \pm 1.32 \\
(8)\end{array}$ & $\begin{array}{l}8.21 \pm 0.76 \\
(20)\end{array}$ \\
\hline $\begin{array}{l}\text { Serum sodium } \\
\quad(\text { meq/l })\end{array}$ & $\begin{array}{l}140.3 \pm 0.63 \\
(4)\end{array}$ & ND & ND & $\begin{array}{l}138.5 \pm 0.3^{\prime \prime} \\
(4)\end{array}$ \\
\hline \multicolumn{5}{|l|}{ Low sodium } \\
\hline $\begin{array}{l}24 \mathrm{~h} \mathrm{U}_{\mathrm{Na}^{+}} \mathrm{V} \\
\quad(m e q)\end{array}$ & - & $\begin{array}{l}0.72 \pm 0.07 \pi \\
(11)\end{array}$ & $\begin{array}{l}0.30 \pm 0.04 \S . \S \S \\
(12)\end{array}$ & $\begin{array}{l}0.22 \pm 0.03 \S \S \S \\
(12)\end{array}$ \\
\hline $\begin{array}{l}\text { Plasma angiotensin II } \\
\quad(p g / m l)\end{array}$ & - & $\begin{array}{l}17.3 \pm 2.2 \\
(8)\end{array}$ & $\begin{array}{l}28.8 \pm 5.8^{* *} \\
(8)\end{array}$ & $\begin{array}{l}108.7 \pm 10.2 \S . \S \S \\
(8)\end{array}$ \\
\hline $\begin{array}{l}\text { Serum sodium } \\
\quad(\mathrm{meq} / \mathrm{l})\end{array}$ & - & ND & ND & $\begin{array}{l}144.8 \pm 1.3^{11} \\
(6)\end{array}$ \\
\hline
\end{tabular}

Data are the mean $\pm \mathrm{SE}$. Numbers in parentheses are the number of independent observations. ND, not done. $\mathrm{U}_{\mathrm{Na}^{\mathrm{a}}} \mathrm{V}$, total urinary sodium excretion. $\ddagger P<0.005$ compared with control. $\S P<0.001$ compared with control. " $P<0.05$ compared with control. I $P<0.05$ compared with high sodium group. ${ }^{* *} P<0.005$ compared with high sodium group. $\$ \S P<0.001$ compared with high sodium group.

of glomerular angiotensin receptors had not been fully investigated. Dietary sodium could regulate angiotensin receptors directly or as a result of changes in circulating hormone. In
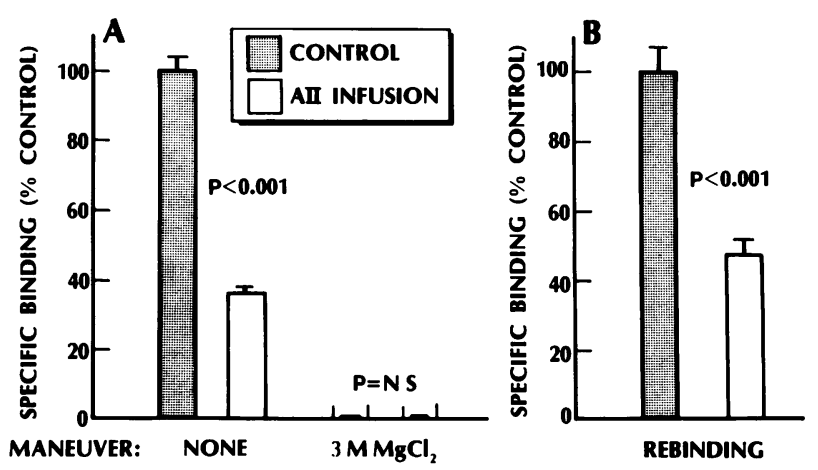

Figure 7. Rebinding experiments. The contribution of receptor occupancy to down-regulation of glomerular angiotensin II receptor density was assessed in glomeruli isolated from normal rats with and without a $15 \mathrm{~min}$ angiotensin II infusion $(100 \mathrm{ng} / \mathrm{min})$. After the addition of ${ }^{125} \mathrm{I}$-angiotnesin II, specific binding was measured under standard incubation conditions (see text). There was a $63.5 \%$ reduction in angiotensin binding after angiotensin II infusion $(A$, left). When $3 \mathrm{M} \mathrm{MgCl}_{2}$ was added to glomeruli, which were preincubated with ${ }^{125}$ I-angiotensin II, there was rapid and complete dissociation of the ligand off its receptor $(A, r i g h t)$. Differences between control glomeruli and glomeruli from angiotensin II-infused rats persisted when rebinding of ${ }^{125} \mathrm{I}$-angiotensin was performed after magnesium chloride treatment $(B)$. one previous study directed at defining the mechanism of sodium-induced regulation of glomerular angiotensin receptors, down-regulation of receptor density in response to salt depletion was reversed by administration of the angiotensin converting enzyme inhibitor, captopril (12). The authors concluded that circulating angiotensin levels mediated the regulation of receptor density, but measurements of plasma angiotensin II were not performed. Our study unequivocally demonstrates the importance of plasma angiotensin II in regulating glomerular angiotensin II receptor density. Using the converse approach, we have demonstrated that up-regulation of receptor density by salt loading could be overcome by angiotensin II infusion. In addition, we have demonstrated that the time course of angiotensin II receptor regulation by sodium in states of sodium surfeit or restriction closely paralleled changes in plasma angiotensin II. At $24 \mathrm{~h}$ after initiating high or low sodium-plus-furosemide regimens there was dissociation between sodium balance and angiotensin II receptor density despite preservation of relationship between plasma angiotensin II and glomerular angiotensin II receptor density. The rapid down-regulation of glomerular angiotensin receptors by acute angiotensin II infusion suggests that receptor density responds rapidly to changes in plasma angiotensin II levels, and the time required for receptor equilibrium in vivo is due to the time required for changes in the plasma hormone.

Experiments investigating the in vitro affects of altering sodium concentration in the media on ${ }^{125} \mathrm{I}$-angiotensin II binding have demonstrated only small effects when media sodium ranged from 50 to $140 \mathrm{meq} / \mathrm{liter}$ in the bovine adrenal 
cortex and rabbit uterus $(19,20)$. In one study on calf cerebellar cortex angiotensin receptors, there was a $25 \%$ increase in angiotensin binding when the concentration of sodium in the medium was increased from 100 to $140 \mathrm{meq} / \mathrm{liter}(21)$. The concentration of the sodium ion used in our in vitro studies was $138 \mathrm{meq} / \mathrm{liter}$ and kept constant for all experiments. Changes in dietary sodium intake were not associated with physiologically significant alterations in the serum sodium in our experiments.

High circulating levels of angiotensin have been associated with increases or decreases in receptor density depending on the tissue under study. In the adrenal gland, for example, angiotensin receptor density is up-regulated by sodium depletion with associated increases in circulating angiotensin II levels (1). In other tissues, including vascular, uterine and bladder smooth muscle, and the renal glomerulus, sodium depletion is associated with a fall in receptor density (17). The mechanism for up-regulation of angiotensin II receptors by circulating hormone in one tissue and down-regulation in other tissues is not understood. It is clear, however, that changes in plasma levels of angiotensin are important for receptor regulation. The molecular basis of changes in receptor density has not been worked out for angiotensin II receptors and is the subject of continued investigation in our laboratory.

The mechanism by which high intake of dietary sodium results in increased angiotensin responsiveness may, at least in part, be explained by our observations. High dietary sodium inhibits the renin-angiotensin-aldosterone system, resulting in low plasma levels of angiotensin II. This in turn leads to upregulation of glomerular angiotensin II receptors, presumably located on the mesangial cell. These cells contain contractile elements, and glomerular diameter is reduced when these receptors are occupied, at least in isolated tissue $(8,22)$. A reduction in mean glomerular diameter would lead to reduced surface area for filtration and lower the glomerular capillary ultrafiltration coefficient, $K_{f}$. Angiotensin binding at the glomerular level might be regulated in one of two ways: There could be changes in hormone-receptor affinity or in receptor density. Our studies clearly demonstrated the influence of circulating angiotensin levels on receptor density, but we were unable to find any differences in hormone-receptor affinity. This is in contrast to the work of Beufils et al. (11) where both the receptor affinity and density were modified by alterations in dietary sodium. The reasons for the conflicting results are not clear, but hormone-receptor affinity in those studies was calculated on the basis of kinetic binding analysis, assuming first-order kinetics; our studies used equilibrium binding and Scatchard analysis.

The modification in angiotensin binding during altered states of sodium balance may have important physiologic implications for the regulation of sodium homeostasis. It is well known that under circumstances of sodium depletion during which increased plasma levels of angiotensin are found, pressor reactivity to infused angiotensin is inhibited $(23,24)$ and the extent of decrease in glomerular filtration rate after administration of angiotensin is also reduced (25). Conversely, during states of sodium surfeit, plasma angiotensin concentration is low and there is both an augmented pressor response $(24,26)$ and fall in glomerular filtration rate (25) when angiotensin is infused. Our data are compatible with these findings and suggest that sensitivity to angiotensin is dependent on receptor density. Our data are also compatible with observations that glomerular filtration rate is modified by acute and chronic changes in sodium balance in the $\operatorname{dog}(27)$ as well as in the rat $(28,29)$, since regulation of angiotensin receptor density by infused hormone in the kidney appears to be complete by $15 \mathrm{~min}$.

The indentification of angiotensin II as a major mediator of sodium-induced modification in glomerular angiotensin receptor density provides an experimental approach for studying angiotensin II receptor regulation in disease states. Abnormalities in angiotensin receptor regulation have been found in certain pathologic states, such as the untreated diabetic rat (30), and have been invoked to explain the altered renal and adrenal angiotensin II responsiveness in human subjects with essential hypertension (31). The recent demonstration that human glomeruli contain specific receptors for angiotensin II make these observations particularly applicable to man (32). Other observations suggest that increased responsiveness to angiotensin II may explain the fall in ultrafiltration seen in malnutrition (33). Further studies are necessary to assess the role of altered glomerular receptor regulation in disease states associated with abnormal sodium handling by the kidney.

\section{Acknowledgments}

We thank Corrine Tomei and Judy Rabin for skillful technical assistance, and Louise Stafutti and Marianne Giattino for typing the manuscript.

This work was supported by grants from the American Heart Association, with funds contributed in part by the American Heart Association-Nassau Chapter, New York, Inc., the New York State Health Research Council, and the National Kidney Foundation of New York, Inc.

\section{References}

1. Aguilera, G., A. Schirar, A. Baukal, and K. H. Catt. 1980. Angiotensin II receptors. Properties and regulation in adrenal glomerulosa cells. Circ. Res. 46:118-127.

2. Sraer, J. D., R. Sraer, R. Ardaillou, and O. Mimoune. 1974. Evidence for renal glomerular receptors for angiotensin II. Kidney Int. 6:241-246.

3. Brown, G. P., and J. G. Dougles. 1982. Angiotensin II binding sites on isolated rat renal brush border membranes. Endocrinology. 6:1830-1836.

4. Mendelsohn, F. A. O., R. Quirion, J. M. Saavedra, G. Aguilera, and K. J. Catt. 1983. Distribution of angiotensin II receptors on rat brain and kidney. Proceedings of the 37th Annual Conference of the Council for High Blood Pressure Research of the American Heart Association. Abstr. No. 32.

5. Blantz, R. C., K. S. Konnen, and B. J. Tucker. 1976. Angiotensin 
II effects upon the glomerular microcirculation and ultrafiltration coefficient of the rat. J. Clin. Invest. 57:419-434.

6. Lohmeier, T. R., A. W. Cawley, Jr., N. C. Trippodo, J. E. Hall, and A. C. Guyton. 1977. Effects of endogenous angiotensin II on renal sodium excretion and renal hemodynamics. Am. J. Physiol. 233:F388F395.

7. Myers, B. D., W. M. Deen, and B. M. Brenner. 1975. Effects of norepinephrine and angiotensin II on the determinants of glomerular ultrafiltration and proximal tubule fluid reabsorption in the rat. Circ. Res. 37:101-110.

8. Wilkes, B. M., W. J. H. Caldicott, G. Schulman, and N. K. Hollenberg. 1981. Loss of glomerular contractile response to angiotensin in rats following myoglobinuric acute renal failure. Circ. Res. 49:11901195.

9. Bernik, M. B. 1969. Contractile activity in human glomeruli in culture. Nephron. 6:1-12.

10. Gunther, S., R. W. Alexander, W. J. Atkinson, and M. A. Gimbrone, Jr. 1982. Functional angiotensin II receptors in cultured vascular smooth muscle cells. J. Cell Biol. 92(2):289-298.

11. Beaufils, M., J. Sraer, C. Lepreux, and R. Ardaillou. 1976. Angiotensin II binding to renal glomeruli from sodium-loaded and sodium-depleted rats. Am. J. Physiol. 235(5):1187-1193.

12. Skorecki, K. L., B. J. Ballerman, H. G. Rennke, and B. M. Brenner. 1983. Angiotensin II receptor regulation in isolated renal glomeruli. Fed. Proc. 42:3064-3070.

13. Hartcroft, P., and A. Eisenstein. 1957. Alterations in the adrenal cortex of the rat induced by sodium deficiency: correlation of histologic changes with steroid hormone secretion. Endocrinology. 60:641-651,

14. Fong, J. S. C., and K. N. Drummond. 1968. Method for preparation of glomeruli for metabolic studies. J. Lab. Clin. Med. 71:1034-1039.

15. Lowry, O. H., N. J. Rosebrough, A. L. Farr, and R. J. Randall. 1951. Protein measurement with Folin phenol reagent. J. Biol. Chem. 193:265-275.

16. Wilkes, B. M., and A. Bellucci. 1983. Properties of glomerular angiotensin receptors in acute renal failure in the rat. J. Lab. Clin. Med. 102:909-917.

17. Aguilera, G., and K. J. Catt. 1981. Regulation of vascular angiotensin II receptors in the rat during altered sodium intake. Circ. Res. 49(3):751-758.

18. Miller, E. D., Jr., D. E. Longnecker, and M. J. Peach. 1979. Renin response to hemorrhage in awake and anesthetized rats. Circ. Shock. 6:271-276.

19. Douglas, J. G., G. Brown, and C. White. 1982. Influence of cations on kinetics of angiotensin II binding to adrenal, renal and smooth muscle receptors. Hypertension. 45:79-84.

20. Glossmann, H., A. Baukal, and K. H. Catt. 1974. Cation dependence of high-affinity angiotensin II binding to adrenal cortex receptors. Science (Wash. DC). 185:281-283.

21. Bennett, J. P., Jr., and S. H. Snyder. 1980. Regulation of receptor binding interactions of ${ }^{125} \mathrm{I}$-angiotensin II and ${ }^{125} \mathrm{I}$-(sarcosine $\mathrm{e}^{1}$, leucin $^{8}$ ) angiotensin II, an angiotensin antagonist, by sodium ion. Eur. J. Pharmacol. 67(1):1-10.

22. Foidart, J. B., J. Sraer, F. Delarue, P. Mahieu, and R. Ardaillou. 1980. Evidence for mesangial glomerular receptors for angiotensin II linked to mesangial cell contractility. FEBS (Fed. Bur. Biochem. Soc.) Lett. 121(2):333-339.

23. Hollenberg, N. K., W. R. Chenitz, D. F. Adams, and G. H. Williams. 1974. Reciprocal influence of salt intake on adrenal glomerulosa and renal vascular responses to angiotensin II in normal man. J. Clin. Invest. 54:34-42.

24. Reid, W. D., and J. H. Laragh. 1965. Sodium and potassium intake, blood pressure and pressor response to angotensin. Proc. Soc. Exp. Biol. Med. 120:26-29.

25. Aurell, M. 1969. Renal responses in man to plasma volume expansion and angiotensin. Scand. J. Clin. Lab. Invest. 24:(Suppl. 112)1-59.

26. Thurston, H., and J. H. Laragh. 1975. Prior receptor occupancy as a determinant of the pressor activity of infused angiotensin II in the rat. Circ. Res. 36:113-117.

27. Carriere, S., P. Boulet, A. Mathieu, and M. G. Brunette. 1972. Isotonic saline loading intrarenal distribution of glomerular filtration in dogs. Kidney Int. 2:191-196.

28. De Rouffignac, C., and J. P. Bonvalet. 1970. Etude chez le rat des variations du debit individuel de filtration glomerulaire des nephrons superficiels et profonds en fonction de l'apport sode. Pfluegers Arch. 317:141-156.

29. Jamison, R. L., and F. R. Lacy. 1971. Effect of saline infusion on superficial and juxtamedullary nephrons in the rat. Am. J. Physiol. 221:690-697.

30. Ballerman, B. J., V. L. Dzau, K. L. Skorecki, and B. M. Brenner. 1983. Altered glomerular angiotensin II receptor modulation in untreated diabetic rats. Kidney Int. 23:272.

31. Williams, G. H., M. L. Turk, J. M. Sullivan, R. G. Dluhey, and N. H. Hollenberg. 1982. Parallel adrenal and renal abnormalities in young patients with essential hypertension. Am. J. Med. 72:907914.

32. Chansel, D., N. Ardaillou, M. P. Nivez, and R. Ardaillou. 1982. Angiotensin II receptors in human isolated renal glomeruli. $J$. Clin. Endocrinol. Metab. 55(5):961-966.

33. Ichikawa, I., M. L. Purkerson, S. Klahr, J. L. Troy, M. Martinez-Maldonado, and B. M. Brenner. 1980. Mechanism of reduced glomerular filtration rate in chronic malnutrition. J. Clin. Invest. 65:982-988. 